\title{
THE PSYCHOLINGUISTIC FACTORS OF INDIRECT TRANSLATION IN UKRAINIAN LITERARY AND RELIGIOUS CONTEXTS
}

\author{
Lada Kolomiyets \\ ladakolomiyets@gmail.com \\ Taras Shevchenko National University of Kyiv, Ukraine
}

\section{Received October 1, 2019; Revised December 12, 2019; Accepted December 24, 2019}

\begin{abstract}
The study of indirect translations (IT) into Ukrainian, viewed from a psycholinguistic perspective, will contribute to a better understanding of Soviet national policies and the post-Soviet linguistic and cultural condition. The paper pioneers a discussion of the strategies and types of IT via Russian in the domains of literature and religion. In many cases the corresponding Russian translation, which serves as a source text for the Ukrainian one, cannot be established with confidence, and the "sticking-out ears" of Russian mediation may only be monitored at the level of sentence structure, when Russian wording underlies the Ukrainian text and distorts its natural fluency. The discussion substantiates the strategies and singles out the types of IT, in particular, (1) Soviet lower-quality retranslations of the recent, and mostly high-quality, translations of literary classics, which deliberately imitated lexical, grammatical, and stylistic patterns of the Russian language (became massive in scope in the mid1930s); (2) the translationfrom-crib type, or translations via the Russian interlinear version, which have been especially common in poetry after WWII, from the languages of the USSR nationalities and the socialist camp countries; (3) overt relayed translations, based on the published and intended for the audience Russian translations that can be clearly defined as the source texts for the IT into Ukrainian; this phenomenon may be best illustrated with Patriarch Filaret Version of the Holy Scripture, translated from the Russian Synodal Bible (the translation started in the early 1970s); and, finally, (4) later Soviet (from the mid1950s) and post-Soviet (during Independence period) hidden relayed translations of literary works, which have been declared as direct ones but in fact appeared in print shortly after the publication of the respective works in Russian translation and mirrored Russian lexical and stylistic patterns.

Keywords: psycholinguistic factors, strategies and types of translation, indirect translation, retranslation, translation-from-crib, relayed translation, intermediary language.
\end{abstract}

Коломісць Лада. Психолінгвістичні фактори опосередкованого перекладу в українському літературному та релігійному контекстах.

Анотація. Дослідження опосередкованих перекладів українською мовою 3 перспективи психолінгвістики допоможе глибше збагнути радянську національну політику та пострадянську мовно-культурну ситуацію. У статті вперше встановлюються й цілісно окреслюються стратегії та типи перекладів, опосередкованих російською мовою, в галузях літератури і релігії. У багатьох випадках неможливо однозначно вказати на відповідні російські переклади, які виступають джерелом для українських текстів, і лише на синтаксичному рівні вдається простежити як крізь українські слова прозирають російські тексти, які руйнують природний плин української мови. Авторка обгрунтовує стратегії та окреслює типи опосередкованого перекладу, зокрема 1) радянські повторні переклади

(C) Kolomiyets, Lada, 2019. This is an Open Access article distributed under the terms and conditions of the Creative Commons Attribution 4.0 International Licence (http://creativecommons.org/licenses/by/4.0).

East European Journal of Psycholinguistics, 6(2), 32-49. https:/doi.org/10.5281/zenodo.3637712 
нижчої якості, ніж нещодавно зроблені якісні переклади класичних творів, які зумисно імітують лексичні, граматичні та стилістичні зразки російської мови (цей тип набув масового характеру з середини 1930-х років); 2) переклад-зі-шпаргалки, тобто переклади через російські підрядники, які були особливо поширеними в жанрі поезії після другої світової війни; 3) відкриті естафетні переклади, які спираються на опубліковані для російської аудиторії російськомовні переклади, що їх можна легко ідентифікувати як джерельні тексти для опосередкованих українських перекладів; найкраще це явище вдалося проілюструвати перекладами Святого Письма, зробленими Патріархом Філаретом 3 російської синодальної Біблії (цю справу було розпочато ще на початку 1970-х років); нарешті, 4) пізньорадянські (з середини 1950-х років) та пострадянські (протягом періоду незалежності) приховані естафетні переклади художніх творів, про які видавці заявляють як про прямі переклади, але їхня фактична поява відразу після публікації відповідних творів російською мовою та лексико-стилістична схожіть на російські відповідники свідчить про їхню опосередкованість.

Ключові слова: психолінгвістичні фактори, стратегії та типи перекладу, опосередкований переклад, повторний переклад, переклад-зі-шпаргалки, естафетний переклад, мова-посередник.

\section{Introduction}

Even though translations via Russian became a mass phenomenon in the $20^{\text {th }}$ century and they still permeate the polysystem of Ukrainian literary, mass media, and religious texts, Ukrainian scholars haven't paid due attention to this phenomenon, with few exceptions (see for instance a $\mathrm{PhD}$ dissertation of Bohdana Pliushch, 2016). Meanwhile, the study of indirect translations into Ukrainian, viewed from a psycholinguistic perspective, will contribute to a better understanding of Soviet national policies and the succeeding post-Soviet linguistic and cultural tendencies. In many cases the corresponding Russian translation, which serves as a source text for the Ukrainian one, cannot be established with confidence, and the "sticking-out ears" of Russian mediation may only be monitored at the level of sentence structure, when Russian wording underlies the Ukrainian text and distorts its natural fluency. The difficulties of establishing the corresponding textual basis for indirect translation are pinpointed by Czech scholar J. Špirk (2014, p. 143).

The basic psycholinguistic factors, put forward for consideration in this study, are the following: (1) human condition, (2) national situation, and (3) cultural agency. The study points to the need to consider the changing habitus of a translator throughout the $20^{\text {th }}$ century, the socio-political environment of the act of translation, and the role of translator as cultural agent. The accommodation of the above psycholinguistic factors may help to build up the necessary links between the strategies, the status, and the agency of indirect translation into Ukrainian via Russian, and not only for the communist past but also for the rather inert in this respect post-communist present.

\section{Methods}

This paper pioneers a discussion of the strategies and types of indirect translation in the domains of literature and religion. It attempts to address a 
multifaceted phenomenon of indirect translation in Ukrainian culture through the prism of psycholinguistic factors, which shape the character of this phenomenon.

The factor of human condition may be specified as the habitus of a translator, broadly understood as "the elaborate result of a personalized social and cultural history" (Simeoni, 1998, p. 32; cited in Jinyu Liu, 2012, p. 1169). According to Jinyu Liu, the habitus of a translator "as a producer may be defined as a durable, transposable disposition acquired by the socialized body, which invests in practice the organizing principles that are socially constructed in the course of a suited and dated experience" (Jinyu Liu, 2012, p. 1169). The habitus includes, but is not restricted to, the translator's age, gender, motivation, self-esteem, source and target language proficiency, translation experience, attitude to and aptitude for translation, as well as applied strategies of translation.

The factor of national situation deals with the socio-political environment of a translator, i.e., the issues of ideology and patronage, the authority and status of the source and target languages, the mass reader education and social profile. The dynamics of Ukrainian socio-political environment in the 20th century reveals a prescriptive, contradictory, and in many respects pernicious governmental policy towards translation in Soviet Ukraine, which promoted literalistic, "second-hand" translations of foreign authors from Russian as a relay language.

The factor of cultural agency brings forward the idea of the translator's mission, a conscious act of translating grounded in the feeling of interconnection between creativity and social change. As formulated in the Synopsis of the book Cultural Agency in the Americas, "Cultural agency' refers to a range of creative activities that contribute to society, including pedagogy, research, activism, and the arts" (Sommer, 2006). The study of indirect translation as a means of cultural agency and a resource of experiments with the normality/abnormality of certain target-language units in various time frames, contributes to a better understanding of cultural processes in the $20^{\text {th }}$-century Ukraine.

In line with H. Pieta \& A. Rosa (2013) and M. Ringmar (2012), I will broadly use the term indirect translation in relation to any translation done from the intermediary language. Also, a different understanding of this term by E.-A. Gutt, built on the theory of relevance by D. Sperber \& D. Wilson (Relevance: Communication and Cognition. Harvard University Press, 1986) turns out to be helpful if applied to censored translations published in Soviet Ukraine. Concerning the interpretation of the original, Gutt distinguishes between a direct translation, which is completely similar with the original, and an indirect translation, which only preserves an "adequate similarity" with it in relevant aspects (Gutt, 1990).

Xi Dong's reasoning for the correction of Gutt's understanding of the term "indirect translation" is noteworthy of attention in the Ukrainian context as well. Dong suggests considering the opposition of "direct" - "indirect" translation rather as the opposite strategies than the types of translation, depending on the translator's decision whether to explicate or not the original author's implications (Xi Dong, 2012 , p. 43). Therefore, a strategically manipulative translation, or "oblique" in 
Vinay \& Darbelnet's model (cited in Munday, 2010, p. 57), is referred to as "indirect" in Gutt and Dong.

To certain type of indirect translations P. Flynn's term "crib translation" (2013) is pertinent. It refers to translation from a crib of a foreign text in the language familiar to the producer of the "next" translation. The intermediary-language crib is necessary in the case if the final target text producer lacks knowledge of the first source text language.

As regards the first target language translations (direct translations), which serve as relay texts for the next-language translations, Danish scholar C. Dollerup advances a typology that distinguishes between 1) translations done for internal use only and 2) those translations that were specifically designed for the first target language audience (Dollerup, 2014, p. 3). For Ukrainian translations based on the published and intended for the audience Russian translations that can be clearly defined as the source (relay) texts for the "next" (relayed) translation, it would be appropriate to adopt the term "relayed translation," suggested by Dollerup (in order to differentiate such a type from other types of indirect translation).

The phenomenon observed by Dollerup (2014) as a relayed translation, when the first translation is chosen as the source text, in fact, relates to the first translation as the original and, thus, does not necessarily involve minimum three languages.

\section{The Study}

In line with Gutt's interpretation of the term indirect translation as the one that does not seek a complete similarity with the original text and meets only the requirement of adequate similarity in pertinent aspects (Gutt, 1990), a number of the 20th-century literary translations, especially of Western authors, may be called "indirect." For instance, this is the case for certain works of Jack London that have been tailored into the Communist Party's ideological weapon (Burghardt, 1939, p. 97).

Built on Gutt's broad understanding of indirect translation as the one being adequately similar, or only enough similar, to the original, Xi Dong's (2012) suggestion to consider the term indirect rather as a strategy, than a type of translation, is suitable for the study of Ukrainian literary context as well. Dong argues that it is the translator's decision between accuracy and relevant adequacy that will determine the character of translation strategy, which in the latter case may be called indirect.

A large group of retranslations into Ukrainian, in which Russian as the third language is not overtly involved, but whose grammatical and stylistic patterns appear to be closely imitative of Russian, came to existence in the mid1930s, with a drive towards Russification of the Ukrainian language and culture and rewriting of the majority of previous translations, which were declared "nationalistic" because they demonstrated multiple differences between the Russian and Ukrainian languages.

This category of lower-quality retranslations hovers between the type of indirect translation, as it is understood by Pieta \& Rosa, and Ringmar, i.e., via the 
third language-mediator, and the type of strategically manipulative translation, which is also called "indirect" by Gutt and Dong.

Among the most telling examples, I cannot but mention The Gadfly, a novel by Ethel Lilian Voynich highly popular in the Soviet Union, which first was published in Ukrainian under the title "Gedz"" in 1929, and then retranslated and printed in 1935 under the Russified title "Ovid" (from Russian: "Ovod"). It is the later version of the novel-abridged and impoverished lexically and stylistically approximating the Russian language patterns-that was reprinted in 1936, 1938, 1955, 1985, and even in independent Ukraine in 2008.

After WWII the category of lower-quality retranslations would be supplemented by a massive phenomenon of translations from Russian-language cribs, if to make use of P. Flynn's term "crib translation" (2013), primarily from the languages of the USSR nationalities and especially in poetry. As applied to Ukrainian literary context, I would rather specify the term "crib translation" as translation-from-crib, when the source text for translation is an interlinear Russian version of a foreign-language original, which serves as a supportive script for the Ukrainian "translator," who lacks knowledge of the first source-text language.

Translations via Russian-language cribs from the national minority languages in Ukraine, especially from Yiddish as the largest after Russian national minority language, were plentiful in the 1920s. In the translation-from-crib, the interim Russian text was not designed for an audience. Anonymous and not for disclosure, it was made only to communicate the source-language message, and primarily to a poet-commissioner who would later versify it. Such was the publishers' editorial policy as well as the social consensus on this issue. This tendency was established as a big move in the second half of the 1930s in accordance with the Communist Party's nationalities policy and its hypocritically declared course at the "friendship of the peoples," when translations became considered an instrument of consolidation of the Soviet Union (Leighton, 1991, p. 18), and after 1945 an instrument of consolidation of the socialist camp.

In accord with C. Dollerup (2014, p. 3), I differentiate between the first target language translations done for internal use only (this category can be exemplified by the abovementioned interlinear Russian-language cribs for Ukrainian writers, who nevertheless were not supposed to give credit to the interim-version authors), and the first target language translations specifically designed for this language audience. In regard to Ukrainian translations based on the published Russian translations as clearly defined source texts, I prefer using the term "relayed translation," adopted from Dollerup.

Alongside translations-from-crib, which have been and still are abundant in social media, relayed translations were commonplace and by no means shameful in the Soviet Union. Nevertheless, Ukrainian literary critics haven't been overtly supportive of relayed translations. Moreover, some of them openly denounced such a strategy as early as the 1920s (Beletskii, 1929/2011, p. 386), but Russian-mediated translations, e.g., Mayne Reid's novel Osceola, vatazhok seminoliv [Osceola the 
Seminole, or, The Red Fawn of the Flower Land] (1928), were mostly successful with the general public.

During the national revival period of the 1920s, French, Polish, English and German, along with the Russian language, could also occasionally serve as relay languages for the translators of Western authors (Kolomiyets, 2015).

Relayed translations took firm root in Ukrainian literary domain as a frequent but covert activity in the post-WWII period. Whole clusters of translations from foreign authors, such as Danish Communist writer Martin Andersen-Nexø, strangely coincided in time with the publication of (multivolume) editions of those authors in Russian. For example, several separate prints of the works by Andersen-Nexø appeared in Ukrainian as alleged translations from Danish the next year after the last volume of the Andersen-Nexø 10-volume Collection of Works saw the light of day in Russian translation (1951-1954). During the later Soviet and post-Soviet decades, the practice of hidden relayed translations, declared as direct ones, continued. In religious context, the facts of relayed translations from Russian have been overt and methodologically justified in the eyes of the Orthodox high clergy by stylistic propensities of (post-)Soviet Ukrainian society.

My suggestion, thus, is to differentiate between the hidden and overt relayed translations. The latter category will be further exemplified by the developments of translation in Ukrainian religious context.

The translation of liturgical books into the living Ukrainian language has been one of the features of Ukrainian national revival in the 1920s and throughout the 20th century. Outstanding church intellectuals were dedicated to the cause of producing as accurate translations as possible from Old Hebrew and Old Greek while creating the solemnity of high biblical style in Ukrainian, with a rhythmical, melodious, and fluent diction. After the liquidation of Ukrainian Autocephalous Orthodox Church in 1930 and mass repressions against its clergy, the published Ukrainian editions of liturgical books were subject to removal and destruction. Ukrainian texts of the Holy Scripture were also proscribed by the Russian Orthodox church, which did not recognize Ukrainian as a language of divine service and demanded that the Bible be read in churches in the Russian redaction of the Old Church Slavonic translation.

The phenomenon of overt relayed translation can be illustrated with Patriarch Filaret Version of the Holy Scripture. By the early 1970s, when Reverend Filaret started his translation of the New Testament from the Russian Synodal Bible (first printing 1876), together with the translation commission consisting of theologians and the Ukrainian language experts, which he had organized specifically for this purpose, the living Ukrainian language became substantially Russified and diluted with a colloquial mixture of Russian and Ukrainian, or the so-called Surzhyk. The general feeling of solemnity of the church language for Soviet Ukrainians began to be tightly bound to the Russian-language liturgical style. This connection was deliberately preserved by Patriarch Filaret in the 1988 New Testament edition and the 2004 entire Bible, both translated from Church Russian of the Synodal Bible (in which the translation of the Old Testament is based on the Jewish Masoretic Text and of the New Testament on the Greek printed editions of mid19th century). 
After 2004, Filaret continues translating and publishing other liturgical books, into which he introduces quotations from the Holy Scripture in his own translation that relies on the Russian Synodal Bible but differs from both the Church Slavonic and the previous Ukrainian liturgical traditions. Filaret explains the success of his translation project by the usage of recognizable "ecclesiastic language" (Filaret, 2018, p. 56-57) in comparison with the strategy of Metropolitan Ilarion (Ivan Ohiienko), who translated the Bible "word-for-word" (doslivno) from Old Hebrew and Old Greek (Ilarion, 1962). Filaret's reasoning for his search of the Ukrainian ecclesiastic language seems rather controversial because he sees the alternative to Ohiienko's view of the biblical language, which for Ohiienko is a melodious and rhythmical language of prayer and soul (Ilarion, 1958, p. 17), ${ }^{1}$ in the language of the Russian Orthodox Church.

\section{Results and Discussion}

\subsection{The changing habitus of a translator}

At the turn from the 1920s to the 1930s, the habitus of Ukrainian translator changed. Consequently, the pre-WWII decade witnessed a gradual recession of translation activity while the number of translations from the third (Russian) language rose. Translations from (and via) Russian were turning into more and more literalistic. Such an adjustment implies that the strategies of translation substantially changed responding to certain changes in socio-political environment. As argued by Lawrence Venuti, "[s]trategies in producing translations inevitably emerge in response to domestic cultural situations," whereas the internal situation in culture is conditioned by several factors, and not only cultural, but also political and economic (Venuti, 2001, p. 240).

At the height of Ukrainization policy in the late 1920s, during its active governmental support (Pauly, 2014), relayed translations of the works of Western classics were not considered acceptable. In order to imagine the difference in attitudes to indirect translation of the classics between the late 1920s and the mid1950s, it would suffice to take a look at a critical review of the first complete Ukrainian translation of The Decameron by the $14^{\text {th }}$-century Italian author Giovanni Boccaccio (Kharkiv, 1929), published in the leading Soviet literary magazine Chervonyi Shliakh [Red Path] in 1930 and written by one of the most significant literary critics of that time Hryhorii Maifet (1930/2011, p. 344-356). In subsequent years, a total blackout regarding any criticism of relayed translation practice would last until Khrushchev's Thaw.

Printed in the amount of 5,000 copies, the 1929 two-volume Ukrainian translation of The Decameron was done from the complete French translation of the book, published by G. Charpentier in Paris in 1879. The two translators, talented

${ }^{1}$ Ohiienko's methodology of translating the Holy Scripture and liturgical books had three basic purposes: (1) enrichment of national language (in particular, by means of rendering the variety of biblical synonyms); (2) inadmissibility of low colloquialisms; and (3) application of metrical verse. The lack of rhythmicity and melodiousness was considered by Ohiienko a substantial disadvantage of the previous high-quality translation of the Bible by Panteleimon Kulish (the 1903 edition). In Ohiienko's view, "the biblical language, the language of prayer, the language of soul, is a melodious language" (Ilarion, 1958, p. 17). 
belletrists Leonid Pakharevskyi and Pavlo Maiorskyi (real mane Sabaldyr), also kept at hand a complete Russian translation of Boccaccio's collected novellas done by Alexander Veselovsky (1891, reprint in 1928). Canzone in the book were translated by one of the best Ukrainian poets Mykola Voronyi. Two literary editors (S. Rodzevych of the first volume, and P. Mokhor of the second one) checked the produced text against the Italian original. As a result, the Ukrainian translation turned out semantically more accurate at some places than Veselovsky's translation of the book; moreover, certain omissions in Veselovsky, resulting from the intrusion of censorship, were rectified in the Ukrainian version. Yet, despite some evident achievements of this edition, it received a harsh criticism from Maifet-just for being a non-direct translation. In particular, the critic argues that "to translate from a translation means to double if not to square all of the collateral semantic overtones" (Maifet, 1930/2011, p. 356). His verdict is that in principle any orientation at a foreign translation, rather than at the original, appears to be false because of its bordering on unacceptable amateurism (Ibid.).

At that time and all the way to the mid1930s, literary translations from a language-mediator could be tolerated by Ukrainian critics rather as the exception, than a daily routine. Exceptions were made for

(1) popular Western authors and social activists whose works were originally written in little-known languages, e.g., a novel by Swedish geographer and travel writer Sven Hedin, translated from German and published by the Knyhospilka cooperative union in 1926 under the title "Zavoiovnyky Ameryky" [The conquerors of America] (Kolomiyets, 2015, p. 80);

(2) proletarian literature and related works by contemporary authors from outside the USSR, particularly those written in little-known languages, e.g., a novel "The True Story of Ah Q" by Chinese writer Lu Xun (real name Zhou Zhangshou), translated into Ukrainian from French and published in 1927 (Kolomiyets, 2015, p. 56);

(3) literary works written in the little-known and minority languages of the USSR nationalities, specifically those that were socialist in spirit or politically engaged with the $\mathrm{CP}(\mathrm{b}) \mathrm{U}$ directives.

It should be noted that translations of Western authors via Russian were rare in the late1920s. They can be exemplified by the following books: two separate editions of short stories by Norwegian author Hans Aanrud - "Rybalchyn syn" [Fisherman's son], published by Kyiv literary circle Chas in 1927, and "Ne takyi, yak usi liudy (opovidannia z zhyttia norvezkykh selian)" [Not like all people (stories from the life of Norwegian peasants)], published by Knyhospilka in Kharkiv in 1930 - both translations were most likely done from the 1919 Moscow (Russian) edition of Aanrud's short stories, entitled "Norvezhskie rasskazy" [Norwegian stories] (Kolomiyets, 2015, p. 259); or, again, two separate editions of the stories of classical Dutch writer Eduard Douwes Dekker (pen name Multatuli) - "Saïd ta Adinda (opovidannia z zhyttia tubiltsiv na ostrovi Yava" [Said and Adinda (A story about the life of indigenous people on the island of Java)], printed by State Publishers of Ukraine in 1927, and "Pid chuzhym yarmom" [Under someone else's 
yoke], published by Knyhospilka in 1929; it is likely that both translations were done from Russian, or at least the latter one, authored by a noted translator from Russian Prokhor Voronyn (Kolomiyets 2015, p. 74).

A large part of the works representing the little-known and minority languages of the USSR have been initially written in Russian, for instance a collection of autobiographic stories "Mudreshkiv syn" [The son of Mudresh] by Kalmyk writer Anton Amur-Sanan and a book "In the Kazakh steppes" by Kazakh author and female activist A. Nukhrat, both editions printed in Ukrainian translation from Russian by the Literatura i Mystetstvo [Literature and Art] publishing house in 1932 (Kolomiyets, 2015, p. 55), or a novel "Zhuttia Imteurgina starshoho" [Life of Imteurgin the Elder] by the classic of Yukagir literature Teki Odulok (real name Nikolai Ivanovich Spiridonov), printed in Ukrainian translation from Russian by Children's Publishing House of the UkrSSR in 1935, the year following its first publication (Kolomiyets, 2015, p. 57).

All the above authors were compelled to use Russian for their works for similar linguistic reasons-because of the Communist reforms of native writing systems that have been crushing minor languages and impairing their natural development. Thus, the Old Kalmyk writing system was to be destroyed and an unsuitable Cyrillic script adopted in 1924. In the same year the Kazakh alphabet, based on Arabic script, underwent a reform bringing it closer to Kazakh phonetics, but in 1929 the Arabic graphics was replaced by JaПalif, or the Latin script-based "new alphabet," in accordance with the Soviet project of Latinization of the Turkic languages aiming to replace the traditional writing systems and create a unified alphabet for minor languages, such as Yukagir, throwing away their oral epic tradition (the Yukagir people, whose autonym is the Odul people, have never had their own writing system, instead their culture found itself deeply rooted in national epos - a unique oral tradition, which compensated for the lack of written texts).

A phenomenon of the USSR nationalities classics who wrote in Russian may be considered, thus, as a type of (self-)translation from the native into the foreign language, and in this respect Russian would covertly play the role of a relay language for the Ukrainian translators of that kind of works.

\subsection{The socio-political environment of the act of translation}

Stalin's political regime destroyed not only the old writing systems and oral traditions, but also the lives of the USSR nationalities writers. The arrest of Teki Odulok (whose pen name originates from Yukagir and means "a little Odul") in 1937 and execution by firing squad in 1938 can best illustrate the Communist Party's intolerance and violent extremism towards any USSR nationality leader, even though this person propagated their rule. By the late 1930s, translations via Russian as a relay language would become an unwritten code that the USSR nationalities translators were supposed to live by. Next to original authors, hundreds of translators would fall victim to the Soviet regime.

From the mid1930s to the mid1950s, relayed translations via Russian (both from published books and interlinear cribs) of the works of Soviet and foreign 
authors were not targeted by the critics at all, having been unofficially justified as fully functional and, thus, granted the status of full value translations.

Lower-quality retranslations of the previous translations, which had been done by outstanding writers and public intellectuals of the 1920s, or the members of the old Ukrainian intelligentsia families, became a frequent occurrence, too. Shifting in the 1930s the just-established norm of translation, with its explicit focus on the original work as the only source for translation, towards an inclusion of Russian language-mediated (re)translations was motived by the necessity of formation of the mass soviet reader.

A reorientation from the original source text to the target mass audience resulted in numerous retranslations of the recent high-quality translations of Western classics. For instance, a famous novel The Life and Strange Surprizing Adventures of Robinson Crusoe (1719) by Daniel Defoe was twice printed by the Kharkiv branch of State Publishers of Ukraine (under the title Zhyttia $i$ dyvni pryhody Robinzona Kruzo) - the first edition in 1927, translated by Halyna Orlivna and abridged by E. I. Zbarska; the second edition in 1929, revised and enlarged by E. I. Zbarska. In 1934 the book appeared in Kharkiv under a slightly modified title, Zhyttia i dyvovyzhni pryhody Robinzona Kruzo, printed by Children's Publishing House, though without any mention of the translator(s). In this form, it would be reprinted in 1936 and 1937. State Publishers of Literature, Derzhlitvydav, printed in Kyiv in 1938 an unabridged version of the novel under the title Zhyttia $i$ chudni ta dyvovyzhni pryhody Robinzona Kruzo, moriaka z Yorka, napysani nym samym [The life and strange surprizing adventures of Robinson Crusoe: of York, mariner; Written by himself]. It was a relayed translation done from the Russian unabridged text, and the translator's name was not mentioned (Kolomiyets, 2015, p. 75).

In post-Soviet Ukraine, abridged versions of the novel have been printed many times, e.g., in 1993 under the title Robinzon Kruzo, without any division of the text into chapters (Kyiv publishing house Kotyhorosko). This version was digitized into an e-book in 2004 by the company Aerius. In 2017 the novel appeared under the title Zhyttia i nezvychaini ta dyvovyzhni pryhody Robinzona Kruzo (Kyiv publishing house Znannia; book series "Treasures: Youth series"), and it was reprinted in 2018 by the same publisher in another book series, "English library," etc. No one of the above editions has ever mentioned the name(s) of the translator(s).

Such examples reflect the fact that from the 1930s, translations from the third language became habitual for a long time, up to and including the present day. The Russian language has played an exclusive role of the only language-mediator, and for translations of political literature it has been a compulsory mediator in the USSR.

A shift in the translation norm towards wide inclusion of Russian-based relayed translations of Western classics, with a literalistic mirroring of Russian texts in new retranslations of the classics, has reshaped the translator's habitus to such as extent that, for instance, the complete translation of the most influential Spanish novel Don Quixote by Miguel de Cervantes, published in Kyiv in 1955, was overtly declared as translation from Russian, done by Vasyl Kozachenko and Yevhen 
Krotevych (it should be duly noted, however, that all of the poems in this edition were directly translated from Spanish by Mykola Lukash) (Kolomiyets, 2015, p. 265).

It was Ukrainian genius translator Mykola Lukash who publicly denounced relayed translations in his speech "Prohresyvna zakhidnoievropeiska literatura $\mathrm{v}$ perekladakh na ukrainsku movu" [Progressive Western European Literature in Ukrainian Translations], delivered at the Republican Conference of Ukrainian Translators in Kyiv on 16 February 1956 (Lukash, 2009). However, the mass production of relayed literalistic translations from Russian endured even in the postSoviet time, and on a more modest scale it continues to this day.

Influenced by the socio-political environment and its dynamics, the shifted norm of translation not only allowed for the existence of impoverished Russianbased literalistic versions of Western classics, but also dictated the importance of translating exclusively from ideologically checked Russian-language texts, bypassing the originals, in the area of social science. Among the most telling examples of a still surviving habit of translating the classics from Russian-language relay texts is the novel The Adventures of Tom Sawyer by Mark Twain.

There has been a plurality of translations of this famed novel in Soviet and post-Soviet Ukraine. As early as 1923 State Publishers of Ukraine printed the book in Odessa, with reprints in 1928 and 1930, but no mention of the translator was made. Children's Publishing House (Kharkiv-Odessa) printed the novel in Yurii Koretskyi's translation in 1935, with reprints in 1948 and 1955 (Kolomiyets, 2015, p. 85). In 1954 a new translation by Volodymyr Mytrofanov appeared, with numerous subsequent reprints, of which the most recent one was published in 2002. Translated by L. Krasavitska, the novel was printed in Kharkiv in 2001, with reprints in 2005, 2006 and 2007. Translated by S. H. Fesenko, it appeared in Donetsk in 2006. A retelling of the novel by V. Levytska saw the light of day in 2009. As argued by the researches, "in part the Ukrainian translations [of this novel] of the recent two decades have a purely commercial purpose and represent a slapdash job relying on various Russian versions" (Solodovnikova, 2017, p. 101).

A similar story happened to the prominent novel by Irish writer Jonathan Swift Gulliver's Travels. It has been printed lots of times, in various versions and volumes. Early abridged translations by Mykola Ivanov appeared in several publishing houses under slightly different titles. In 1928 State Publishers of Ukraine (Kyiv) printed Mandry Gulliverovi, Children's Publishing House (Kharkiv-Odessa) brought out Podorozhi Gullivera in 1935 (reprinted in 1938 in Kharkiv under the title Mandry Gullivera) and Gulliver $u$ liliputiv in 1937. State Publishers of Literature (Kyiv-Kharkiv) printed Mandry do riznykh dalekykh krain svitu Lemiuelia Gullivera in 1935. Translated by G. Zaitsev, a chapter of the novel Podorozh Gullivera do krainy liliputiv was published by Knyhospilka cooperative union in 1929 (Kolomiyets 2015, p. 79).

After WWII there was a ban on the name of Mykola Ivanov, and partially on his translations, because he fled to Germany during WWII where his trace was lost. The researchers admit, anyway, that Ivanov died somewhere in Siberia, in the 
concentration camp, after being caught by the NKVD agents and sent back to the USSR.

Still, the 1976 edition of Swift's novel under the full title Mandry do riznykh dalekykh krain svitu Lemiuelia Gullivera, spochatku likaria, a potim kapitana kilkokh korabliv [Travels into Several Remote Nations of the World of Lemuel Gulliver, First a Surgeon, and then a Captain of Several Ships] (Kyiv: Veselka) mentions only the name of Yurii Lisniak as the translator from English, although for the most part Lisniak was an editor of Ivanov's work. In 1983 the book appeared in the series "Tops of World Literature" (volume 47) under the title Mandry Gulivera [Gulliver's Travels] (Kyiv: Dnipro), with the name Yurii Lisniak as the translator from English.

Below I will survey only the print editions of the novel in Ukrainian, leaving aside its multiple digitized versions. Thus, Mykola Ivanov was mentioned again as translator in the 2004 edition of the novel by Kharkiv publishing house Folio, entitled Mandry do riznykh dalekykh krain svitu Lemiuelia Gullivera, spershu likaria, a potim kapitana kilkokh korabliv (reprint in 2013).

The following year, Children's Publisher A-BA-BA-HA-LA-MA-HA in Kyiv printed a beautifully illustrated edition of the book, Mandry Gullivera, admitting Mykola Ivanov as translator from English and Rostyslav Dotsenko as editor. The book has been reprinted 4 times (in the series "Books that transcended time").

That same year Kyiv publishing house Shkola printed the book Mandry do riznykh dalekykh krain svitu Lemiuelia Gullivera, spochaktu likaria, a potim kapitana kilkokh korabliv, with mention of Mykola Ivanov as translator from English and Yurii Lisliak as editor. This edition was reprinted under the cover page title Mandry Lemiuelia Gullivera in the series "Children's world best seller" in 2010 (Kyiv: National Book Project).

Mykola Ivanov is also recognized as translator from English in the 2016 edition of the novel (nonetheless, no editor is mentioned) by Kyiv publishing house Znannia, entitled Mandry do riznykh viddalekykh krain svitu Lemiuelia Gullivera, spershu likaria, a potim kapitana kilkokh korabliv (in the series "Treasures: Youth Series").

The 2009 edition under the title Mandry Gullivera by Kyiv publishing house Kraïna mrii (series "Favorite books," section "Vsevolod Nestaiko radyt pochytaty") was reprinted in 2010, 2011, and 2013. This edition gives a vague and suspicious reference to who and how did the translation - "per. [tr.] L. Borsuk." It turns out in later editions, though, that the text has been adapted (not translated!) - "perekaz. z angl. [retold from Engl. by] L. Borsuk." A slightly more correct categorization "retold for children by O. A. Volosevych" - the reader would find in the book Mandry Gulivera u Liliputiui ta krainu veletniv [Gulliver's Travels to Lilliputia and the land of giants], printed by Lviv publishers Avers in 2001, which also specifies the category of readers: "for primary and lower-secondary school age." Still, the source text for "retelling" is not indicated in this edition. The next year's printing of the novel, Mandry do riznykh dalekykh krain svitu Lemiuelia Gullivera, spershu likaria, a potim kapitana kilkokh korabliv, by Lviv publishers Chervona Kalyna 
should supposedly - judging from the title - contain the unabridged version. Nevertheless, the source text is not mentioned at all, nor the translator(s) or editor(s). Instead, the publishers inform their readers that the novel "is compiled" (?!) ("uporiad.") by L. Fedoriv.

Amidst the variety of unadmitted relayed translations and adaptations, the 2011 edition, Mandry Gullivera, by Kharkiv Book Club publishers "Family Leisure Club" (series "Adventure Library"), specified "for lower-secondary school age," stands out as a rare exception. This is the only Ukrainian edition of Swift's novel that overtly gives reference to the Russian-language translation as its relay source text, referring to the book Puteshestviia Gullivera, published in Belgorod in 2010. But there's more. In the book description section, the reader will find information on how the Russian source text has been handled. It turns out that one person has translated it ("per. [tr.] Halyna Fursa") and another person adapted ("adapt. [adapt. by] Andriia Klimova").

\subsection{The role of translator as cultural agent}

During the years of colonial dependence upon Russian ideological, cultural, and religious dictatorship, Ukrainian translation has been carrying out a double mission: one was liberating and nation-building, another Sovietizing and Russifying.

Many important Ukrainian intellectuals of the 20th century have treated and practiced translation as a conscious choice of the way to serve God, their nation, language, and culture. Translational action of Patriarch Filaret, who acted as an inspirator, coordinator, mentor, and translator himself, aimed at creating a new translation of the Holy Scripture into the living Ukrainian language as the most suitable for the present-day Ukrainian Christians, the most inclusive and efficient with the Ukrainian Church parishioners, stands out as a prominent example in that regard.

The methodology of relayed translation applied by Filaret (secular name Mykhailo Denysenko; born on 23 January 1929 into a Ukrainian-speaking family of Anton and Melania Denysenko), with the focus on the Russian Synodal Bible, was rooted both in the individual and national history, in Patriarch's provenance from the village of Blahodatne in the Donetsk Oblast (province) in Eastern Ukraine. The Ukrainian identity and the language choice were never questioned in the family of Denysenkos. It was simply natural for this family, as well as for other families from the village of Blahodatne, to be Ukrainians and to speak Ukrainian (Filaret 2018, pp. 66-67). Mykhailo's father worked at the local cement plant, as many of his covillagers did. When the Artificial Famine (the Holodomor) struck, he managed to save his family from hunger death thanks to a miraculously lucky employment in the nearby mine shafts, where normally only the non-local people (non-Ukrainians) were permitted to work. Those workers were imported mostly from the Russian Federation and from all over the USSR when Stalin declared the industrialization of the Donbass. As a memoirist, Filaret maintains that the mine workers, who were predominantly ethnic Russians, received a regular bread ration whereas the plant 
workers from the surrounding Ukrainian villages were destined to die from starvation (ibid.)

Having been raised as Ukrainian-speaking individual, Mykhailo Denysenko obtained his theological education in the fold of Moscow Patriarchate: at the Odessa Seminary and the Moscow Theological Academy. As a consistent reformer of the Orthodox Church in Ukraine and its Ukrainizer in the later Soviet and post-Soviet decades, Filaret was seeking in the Ukrainian language of the Bible the variant of the language he was used to, with a habitual naturalness of the Central-Ukrainian dialect, which has formed the basis for the literary Ukrainian language in the UkrSSR. The living fluency and solemnity of high biblical style in Filaret's translation strategy is not distanced from Church Slavonic lexical patterns and their Russian equivalents, nor is it severed from the solemnity of high biblical style in the Russian language. Filaret set out his reasons for a new translation of the Bible based on the belief that the previous translation by Ivan Ohiienko ${ }^{1}$ has not been read and acclaimed by Ukrainians (particularly in Ukraine) because its language doesn't feel as an ecclesiastic/church language. Having realized that fact, Filaret set the aim to retranslate the Bible so that the Ukrainians could feel an ecclesiastic solemnity of its language (Filaret, 2018, p. 56-57). ${ }^{2}$

From the political history perspective, the story of Filaret's translation of the New Testament has been tightly intertwined with the warming of political regime in the Ukrainian Soviet Socialist Republic. The translation was ready for publication as early as 1971, when Petro Shelest (1908-1996), the First Secretary of the Communist Party of the Ukrainian SSR and a member of the Politburo of the Communist Party of the Soviet Union, made a protection for it. During his tenure, there was a brief resurgence of the Ukrainian national culture. Filaret created a commission of theologians and experts in the Ukrainian language, which translated the New Testament. It was submitted to the Council on Religions. In 1972 Shelest was transferred to the post of deputy chairman of the USSR Council of Ministers as a result of political "intrigues" of his successor, but also because Shelest "was Ukrainizing Ukraine," as Filaret admitted in his autobiographic interview. Consequently, the Ukrainian translation of the New Testament was ordered to be destroyed. However, as Filaret admits, a copy of it was fortunately saved (Filaret, 2018, p. 57).

The Filaret Version of the Bible has now been accepted by all Ukrainian churches and reprinted separately with Greek Catholics, Roman Catholics, and Protestants. This translation can be generally characterized as a "modernized" one (Dzera, 2014, p. 219).

\footnotetext{
${ }^{1}$ During WWII, there appeared a separate edition of the New Testament - The New Testament of our Lord and Savior, Jesus Christ. Translated from Greek by Ivan Ohiienko («Новий Заповіт» Господа й Спасителя нашого Ісуса Христа. 3 грецької переклав Іван Огієнко) - together with The Book of Psalms. Translated from Old Hebrew by Ivan Ohiienko (Книга Псалмів. 3 давньоєврейської переклав Іван Огієнко). The book was published in Stockholm in 1942. The entire Bible in Ohiienko's translation saw the light of day only in 1962.

2 “'[О]сь переклав Огієнко Біблію українською мовою - професор, знавець української мови, а Біблію його не читали, не хотіли. Я сам цікавився свого часу, чому Біблію українською мовою не беруть люди-українці? Потім я зрозумів, мова - не церковна. Не церковна мова. I тому я поставив завдання: перекласти знову Біблію українською мовою, але так, щоб мова була церковна” (Filaret, 2018, p. 56-57).
} 


\section{Conclusion}

The discussion in this paper substantiates the strategies and psycholinguistic factors of various types of indirect translation, such as (1) Soviet lower-quality retranslations of the recent, and mostly high-quality, translations of literary classics, which deliberately imitated lexical, grammatical, and stylistic patterns of the Russian language (became massive in scope in the mid1930s); (2) the translationfrom-crib type, or translations via the Russian interlinear version, which have been especially common in poetry after WWII, from the languages of the USSR nationalities and the socialist camp countries; (3) overt relayed translations, based on the published and intended for the audience Russian translations that can be clearly defined as the source texts for the indirect translation into Ukrainian; this phenomenon may be best illustrated with Patriarch Filaret Version of the Holy Scripture, translated from the Russian Synodal Bible (the translation started in the early 1970s); and, finally, (4) later Soviet (from the mid1950s) and post-Soviet (during Independence period) hidden relayed translations of literary works, which have been declared as direct ones but in fact appeared in print shortly after the publication of the respective works in Russian translation and stylistically mirrored the Russian patterns.

\section{References}

Белецкий, А. Переводная литература на Украине // Красное слово. 1929. № 2. С. 87-96. Цит за вид.: Кальниченко О. А., Полякова Ю. Ю. Українська перекладознавча думка 1920-х початку 1930-х років: Хрестоматія вибраних праць 3 перекладознавства до курсу «Історія перекладу» / Укладачі Л. Черноватий і В. Карабан. Вінниця: Нова Книга, 2011. С. 376391.

Бурггардт, Осв. Большевицька спадщина // Вістник. 1939. № 1, Кн. 2. С. 94-99.

Dollerup, C. (2014). Relay in Translation. Cross-linguistic Interaction: Translation, Contrastive and Cognitive Studies. Liber Amicorum in Honour of Prof. Bistra Alexieva published on the occasion of her eightieth birthday, Diana Yankova, (Ed.). (pp. 21-32). St. Kliminent Ohridski University Press. Retrieved from https://cms13659.hstatic.dk/upload_dir/ docs/Publications/232-Relay-in-translation-(1).pdf

Dong, Xi (2012). A Probe into Translation Strategies from Relevance Perspective-Direct Translation and Indirect Translation. Canadian Social Science, 8(6), 39-44. Retrieved from http://www.cscanada.org/index.php/css/article/viewFile/j.css.1923669720120806.9252/3281

Дзера, О. Історія українських перекладів Святого Письма // Іноземна філологія. 2014. Вип. 127, Ч. 2. С. 214-222.

Філарет, Патріарх Київський та всієї Руси-України, Василь Шкляр, Микола Вересень, В'ячеслав Кириленко. Розмова В'ячеслава Кириленка із Патріархом Київським та всієї Руси-України Філаретом. Віра. У кн.: Три розмови про Україну. Упорядник та радактор В. Кириленко. Х.: Книжковий Клуб «Клуб Сімейного Дозвілля», 2018. С. 9-92.

Flynn, P. (2013). Author and Translator. In Yves Gambier, Luc van Doorslaer (Eds.), Handbook of Translation Studies, 4, (pp. 12-19). Amsterdam / Philadelphia: John Benjamins Publishing Company.

Gutt, E.-A. (1990). A theoretical account of translation - without a translation theory. Retrieved from http://cogprints.org/2597/1/THEORACC.htm

Коломієць Л. В. Український художній переклад та перекладачі 1920-30-х років: матеріали до курсу «Історія перекладу». Вінниця: «Нова книга», 2015. 
Іларіон, митр. Біблія - найперше джерело для вивчення своєї літературної мови / Митр. Іларіон // Віра і культура. 1958. Ч. 6 (66). С. 13-17.

Іларіон, митр. Біблія, або Книги Святого Письма Старого и Нового Заповіту. Із мови давньоєврейської й грецької на українську дослівно наново перекладена. United Bible Societies, 1962.

Jinyu L. (2012). Habitus of Translators as Socialized Individuals: Bourdieu's Account. Theory and Practice in Language Studies, 2(6), 1168-1173.

Leighton, L. (1991). Two Worlds, One Art. Literary Translation in Russia and America. DeKalb, Ill.: Northwestern Illinois UP.

Лукаш М. Прогресивна західноєвропейська література в перекладах на українську мову // Протей [редкол. О. Кальниченко (голова) та ін.]. Вип. 2. Х.: Вид-во НУА, 2009. С. 560-605.

Майфет, Г. [Рецензія] // Червоний шлях. 1930. № 2. С. 252-258. Рец. на кн.: Боккаччо Дж. Декамерон / пер. Л. Пахаревського та П. Майорського; ред. С. Родзевича та П. Мохора; вступ. ст. В. Державіна. [Харків]; ДВУ, 1929. Ч. 1. XXXI, 408 с.; Ч. 2. Цит за вид.: Кальниченко О. А., Полякова Ю. Ю. Українська перекладознавча думка 1920-х початку 1930-х років: Хрестоматія вибраних праць з перекладознавства до курсу «Історія перекладу» / Укладачі Л. Чернований і В. Карабан. Вінниця: Нова Книга, 2011. С. 344356.

Munday, J. (2010). Introducing Translation Studies: Theories and Applications. 2nd Ed. London \& New York: Routledge.

Pauly, M. D. (2014). Breaking the Tongue: Language, Education, and Power in Soviet Ukraine. Toronto Buffalo London: University of Toronto Press.

Pieta, H. \& Rosa, A. A. (2013). Panel 7: Indirect translation: exploratory panel on the state-of-theart and future research avenues. $7^{\text {th }}$ EST Congress - Germersheim, 29 August -1 September 2013. Retrieved from http://www.fb06.uni-mainz.de/est/51.php

Плющ, Б. О. Прямий та неопрямий переклад української художньої прози англійською, німецькою, іспанською та російською мовами. Дис. ...канд. філол. наук., Київ: КНУ імені Тараса Шевченка, 2016.

Ringmar, M. (2012). Relay translation. In Yves Gambier, Luc van Doorslaer (Eds.), Handbook of Translation Studies, 4 (pp. 141-144). Amsterdam / Philadelphia: John Benjamins Publishing Company.

Simeoni, D. (1998). The pivotal status of the translator's habitus. Target, 10(1), 1-39.

Солодовнікова, М. І. Відтворення стилістичних особливостей роману Марка Твена «Пригоди Тома Сойера» в українських перекладах: квантитативний аспект // Перспективи розвитку філологічних наук: Матеріали III Міжнародної науковопрактичної конференції (Хмельницький, 24-25 березня). Херсон: вид-во «Гельветика», 2017. C. 99-103.

Sommer, D, ed. (2006). Cultural Agency in the Americas. [Synopsis]. Durham, NC: Duke University Press. Retrieved from https://www.amazon.co.uk/Cultural-Agency-AmericasDoris-Sommer/dp/0822334992

Špirk, J. (2014). Censorship, Indirect Translations and Non-translation: The (Fateful) Adventures of Czech Literature in 20th-century Portugal. Newcastle upon Tyne: Cambridge Scholars Publishing.

Venuti, L. (2001). Strategies of Translation. In M. Baker (Ed.). Routledge Encyclopedia of Translation Studies, (pp. 240-244). London \& New York: Routledge.

\section{References (translated and transliterated)}

Beletskii, A. (1929). Perevodnaia literatura na Ukraine [Translated literature in Ukraine]. Krasnoe Slovo [Red Word], 2, 87-96. Reprint in: Kalnychenko, O. A. and Poliakova, Yu. (2011). In L. Chernovatyi \& V. Karaban (Eds.). Ukraiins'ka perekladoznavcha dumka 1920-kh - 
pochatku 1930-kh rokiv: Khrestomatiia vybranykh prats z perekladosnavstva do kursu "Istoriia perekladu" [Ukrainian translation studies of the 1920s - early 1930s: A textbook of selected works in translation studies for a course on the "History of Translation"]. (pp. 376-391). Vinnytsia: Nova Knyha,

Burghardt, O. (1939). Bolshevytska spadschyna [The Bolsheviks' heritage]. Vistnyk, 1, Book 2, 94-99.

Dollerup, C. (2014). Relay in Translation. Cross-linguistic Interaction: Translation, Contrastive and Cognitive Studies. Liber Amicorum in Honour of Prof. Bistra Alexieva published on the occasion of her eightieth birthday, D. Yankova, (Ed.). (pp. 21-32). St. Kliminent Ohridski University Press. Retrieved from https://cms13659.hstatic.dk/upload_dir/ docs/Publications/232-Relay-in-translation-(1).pdf

Dong, Xi (2012). A Probe into Translation Strategies from Relevance Perspective-Direct Translation and Indirect Translation. Canadian Social Science, 8(6), 39-44. Retrieved from http://www.cscanada.org/index.php/css/article/viewFile/j.css.1923669720120806.9252/3281

Dzera, O. (2014). Istoriia ukraiinskykh perekladiv Sviatoho Pysma [History of Ukrainian translations of the Holy Scripture]. Inozemna Filologiia, 127, Part 2, 214-222.

Filaret, Patriarch of Kyiv and all Rus-Ukraine et al. (2018). Rozmova Viacheslava Kyrylenka iz Patriarkhom Kyivskym ta vsiiei Rusy-Ukrainy Filaretom. Vira [A Conversation of Viacheslav Kyrylenko with Patriarch of Kyiv and all Rus-Ukraine Filaret. Faith]. In: Try rozmovy pro Ukrainu [Three Conversations about Ukraine], compiled and edited by V. Kyrylenko. Kharkiv: Family Leisure Club, 9-92.

Flynn, P. (2013). Author and Translator. In Y. Gambier, L. van Doorslaer (Eds.), Handbook of Translation Studies, 4, (pp. 12-19). Amsterdam / Philadelphia: John Benjamins Publishing Company.

Gutt, E.-A. (1990). A theoretical account of translation - without a translation theory. Retrieved from http://cogprints.org/2597/1/THEORACC.htm

Kolomiyets, L. (2015). Ukraiinskyi khudozhniy pereklad ta perekladachi 1920-30-kh rokiv: Materialy do kursu "Istoriia perekladu" [Ukrainian Literary Translation and Translators in the 1920s-30s: "History of translation" course materials]. Vinnytsia: Nova Knyha.

Ilarion, Metropolitan (1958). Bibliia - naipershe dzherelo dlia vyvchennia svoiei literaturnoi movy [The Bible is the first source for studying our literary language]. Vira i kultura [Faith and Culture], No. 6 (66), 13-17.

Ilarion, Metropolitan. 1962. Bibliia abo Knyhy Sviatoho Pusma Staroho i Novoho Zapovitu. Iz movy davnioievreiskoi i hretskoi na ukrainsku doslivno nanovo perekladena. Commissioned by United Bible Societies.

Jinyu L. (2012). Habitus of Translators as Socialized Individuals: Bourdieu's Account. Theory and Practice in Language Studies, 2(6), 1168-1173.

Leighton, L. (1991). Two Worlds, One Art. Literary Translation in Russia and America. DeKalb, Ill.: Northwestern Illinois UP.

Lukash, M. (2009). Prohresyvna zakhidnoievropeiska literatura v perekladakh na ukraiinsku movu [Progressive West European Literature in Ukrainian]. Protei, 2. O. Kalnychenko, Ed.

Kharkiv: Vydavnytstvo NUA, 560-605.

Maifet, H. (1930). [Review]. Chervonyi Shliakh [Red Path], 2, 252-258. Review of the book: Boccaccio G. Decameron. Tr. by L. Pakharevskyi and P. Maiorskyi; S. Rodzevych and P. Mokhor (Eds.); introduction by V. Derzhavyn. Kharkiv: DVU, 1929. Part 1. XXXI; Part 2. Reprint in: Kalnychenko, O. and Poliakova, Yu. (2011). In L. Chernovatyi \& V. Karaban (Eds.). Ukraiins 'ka perekladoznavcha dumka 1920-kh-pochatku 1930-kh rokiv: Khrestomatiia vybranykh prats z perekladosnavstva do kursu "Istoriia perekladu" [Ukrainian translation studies of the 1920s - early 1930s: A textbook of selected works in translation studies for a course on the "History of Translation"]. (pp. 344-356). Vinnytsia: Nova Knyha. 
Munday, J. (2010). Introducing Translation Studies: Theories and applications. 2nd Ed. London \& New York: Routledge.

Pauly, M. D. (2014). Breaking the Tongue: Language, Education, and Power in Soviet Ukraine. Toronto Buffalo London: University of Toronto Press.

Pieta, H. \& Rosa, A. A. (2013). Panel 7: Indirect translation: exploratory panel on the state-of-theart and future research avenues. $7^{\text {th }}$ EST Congress - Germersheim, 29 August -1 September 2013. Retrieved from http://www.fb06.uni-mainz.de/est/51.php

Pliushch, B. (2016). Direct and Indirect Translations of Ukrainian Literary Prose into English, German, Spanish and Russian. PhD thesis. Manuscript copyright. Kyiv: Taras Shevchenko National University of Kyiv.

Ringmar, M. (2012). Relay translation. In Y. Gambier, L. van Doorslaer (Eds.), Handbook of Translation Studies, 4 (pp. 141-144). Amsterdam / Philadelphia: John Benjamins Publishing Company.

Simeoni, D. (1998). The pivotal status of the translator's habitus. Target, 10(1), 1-39.

Solodovnikova. M. I. (2017) Vidtvorennia stylistychnykh osoblyvostei romanu Marka Tvena "Pryhody Toma Soiera" v ukrainskykh perekladakh: kvantytatyvnyi aspekt. Perspektyvy rozvytku filolohichnykh nauk: Book of abstracts of III International Scientific Conference (Khmelnytskyi, 24-25 March). Kherson: Helvetyka Publishing House. (99-103).

Sommer, D., Ed. (2006). Cultural Agency in the Americas. [Synopsis]. Durham, NC: Duke University Press. Retrieved from https://www.amazon.co.uk/Cultural-Agency-AmericasDoris-Sommer/dp/0822334992

Špirk, J. (2014). Censorship, Indirect Translations and Non-translation: The (Fateful) Adventures of Czech Literature in 20th-century Portugal. Newcastle upon Tyne: Cambridge Scholars Publishing.

Venuti, L. (2001). Strategies of Translation. In M. Baker (Ed.). Routledge Encyclopedia of Translation Studies. (pp. 240-244). London \& New York: Routledge. 